\title{
ATTENDEE MOTIVATIONS AT AN INTERNATIONAL WINE FESTIVAL IN CHINA
}

\author{
MICHAEL O’REGAN,* JAEYEON CHOE,* AND MATTHEW YAP† \\ *Bournemouth University, Poole, UK \\ $\dagger$ Faculty of Business Administration, University of Macau, Taipa, Macau
}

\begin{abstract}
Wine festival research has primarily focused on tourism potential and economic impact in Western wine destinations, with few studies seeking to understand what motivates those to attend a festival in a "nontraditional" wine destination. An onsite survey study $(N=366)$ was conducted at the 2012 Dalian International Wine and Dine Festival, China. Factor analysis suggests a unique motivational factor structure with four motivational components identified among festival attendees. They were: wine festivalwhere the festival event itself is a primary motive, recover equilibrium at a novel event, family and known group togetherness, and cultural exploration through interaction/socialization. An independent $t$ test and one-way ANOVA tests found statistically significant motivational variances between attendees based on gender, age, education, income level, and employment status. These findings offer important implications for festival and event organizations that have an interest in developing and organizing wine festivals in China, and attracting Chinese mainland tourists to overseas wine festivals.
\end{abstract}

Key words: Wine festivals; Festival motivation framework; Visitors' motivation; China; Culture

Introduction

Since the late 1970s, the People's Republic of China (PRC) has been transformed from a closed agrarian socialist economy to an urban state and a global economic force (Ma, 2002). Economic growth has created an aspirational middle class chasing what the Communist Party (CPC) General Secretary, and now President of the PRC, Xi Jinping called the "Chinese Dream” (Zhōngguó mèng) in
2012. Although the phrase purportedly describes prosperity, collective effort, and socialism, it also illustrates the consumption habits of an emerging middle class. Although their consumption habits have been associated with public and visible material goods, the middle class are increasingly associated with a rapid growth in "experiential" sectors, such as fine wine consumption and emergent cultural events, such as wine festivals. According to the International Organization of Vine and Wine 
(OIV, 2015), China is likely to become the world's second-largest wine consuming country by 2016, after it became the second-largest wine growing area in the world after Spain in 2014. Although attention has focused on these headline-grabbing announcements, as well as construction of chateaux as flag ships for domestic wine producers, wine schools, and wine theme parks (Dong \& Yang, 2011), researchers have not fully explored more nuanced understandings about Chinese interest in wine and related consumption habits. Research hasn't explored visits to domestic and foreign wineries, Chinese wine growing regions, wine-related events such as wine festivals and wine education programs offered by wineries, distributors, consultants, and universities.

Although the motives of individuals attending wine events in wine destinations are well represented in the West, little is known about the kinds of people who attend wine festivals in China, and what motivates them to do so. Although there is a small but growing body of literature on festival attendee's motivations in China (e.g., Y-N. Li \& Wood, 2016), researchers are still unsure as to whether instruments designed by Western researchers are adaptable to China and the extent to which festival attendance is "universally" motivated (Dewar, Meyer, \& Li, 2001). Research at a Chinese music festival by Y-N. Li and Wood (2016) found that although attendees have some similar motivations to those in Western studies, certain dimensions were more specific to festival goers in Mainland China. However, Dewar et al. (2001) found that the motivational scales developed for festival attendees in North America were readily transferred to the Harbin Ice Lantern and Snow Festival in China. Therefore, motivational frameworks generated from studies in the West may not be applicable to China given the different cultural conditions.

Therefore, although motivations are at the heart of this study, and indeed event studies, wine festivals are an underresearched phenomenon in mainland China. Therefore, the main study objective is the exploration of motivating factors at the 2012 Dalian International Wine and Dine Festival, and whether motivating factors are influenced by the particular social, demographic, political, and cultural factors at work in China. As well as focusing on the cross-cultural validation of motivation theories (Steers, Mowday, \& Shapiro, 2004), this study profiles wine festival attendees. Finally, the study identifies the push and pull motives essential for a wine festival marketing strategy, and provides managerial and marketing guidance to event, festival, and national destination managers based on the specific motivations found in the study.

\section{Literature Review}

\section{Wine Tourism and Wine Festivals}

Since the emergence of wine as a niche tourism product (Hall, 1996), research within tourism, hospitality, and event studies has firmly linked wine festivals to recreation and tourism (Carlsen, 2004; Carlsen \& Charters, 2004; Getz, 2000). Hall (1996) defines wine tourism as "visitations to vineyards, wineries, wine festivals and wine shows for which grape wine tasting and/or experiencing the attributes of a grape wine region are the prime motivating factors for visitors” (p. 197). By attracting people interested in wine, wine festivals have become a key element of both the wine and tourism industries (J. J. Yuan, Cai, Morrison, \& Linton, 2005a, 2005b). As wine regions have been at the forefront of developing festivals as part of a total wine (tourism) experience, the majority of wine festival studies tend to take place within large wine producing regions and wine tourism destinations. In addition, such studies naturally link festivals with wine tourism development (J. J. Yuan et al., 2005a; J. J. Yuan, Morrison, Cai, \& Linton, 2008). By promoting networks between various wine attractions, traders, and merchants, wine regions in countries such as Australia, Italy, Spain, and Portugal have successfully reached out to the tourism industry and even national authorities in creating and successfully marketing wine festivals (Brown \& Getz, 2006). Within this context, wine festival research within wine regions indicates that festivals can attract significant numbers of visitors and help build loyalty to wineries and wine merchants, as well as strengthen, enhance, or change a destinations brand (Arnold, 1999; Jago, Chalip, Brown, Mules, \& Ali, 2003; J. J. Yuan et al., 2008).

Despite a growing number of wine festival studies, few festival-related studies focus on wine festivals that lack an accompanying wine growing region. As 
wine (as well as mixed wine and dine) festivals multiply without having links to wine regions or any historical wine culture, city-based festivals have merged wine with city infrastructure to showcase wine and promote the attractiveness of a destination. As location comes to be seen as contributing to the overall success of such events (Taylor \& Shanka, 2002), cities offer a convenient and appealing location for a broader range of wine festival participants (J. J. Yuan et al., 2005a). Therefore, wine festivals, we argue, should be seen more broadly as special occasions where attendees actively engage for "the satisfaction of their interest in wine and/or for the entertainment made available by other leisure activities” (J. J. Yuan et al., 2005a, p. 43).

One such city wine festival is the Dalian International Wine and Dine Festival (首届大连国际葡 萄酒美食节). Its inaugural festival in 2012, July $12-15$, was promoted as the first national wine festival of China. It was jointly organized by the local government of Dalian, China National Light Industry Council, Dalian Haichang Group, the French Chamber of Commerce, and Industry of Bordeaux in 2012. Dalian is a second-tier city in Northeast China's Liaoning Province and has been identified as being a future dynamic city, with continuous double-digit increases in GDP and a population of approximately 6.7 million people. During the festival, 60 French vintners from Bordeaux were present, among 300 other vintners from 30 countries and regions around the world. The event attracted 80,000 attendees. Statistics from the organizing committee show that 100,000 bottles of wine were sold, 1,000 contracts signed, and wines sold in auction were valued at about US\$3.5 million. The event included various activities such as wine tasting, a wine auction, and lectures on wine appreciation.

\section{Wine Festival Motivations}

Although wine tourist research indicates a wide variety of wine tourist characteristics (Charters \& Ali-Knight, 2002; Mitchell \& Hall, 2006), wine festival research largely assigns wine festival attendees and their motivations as a minor component of an overall holiday experiences in, or adjacent to, the core wine regions and wineries. Such studies have collected data on demographics and purchasing behavior (Mitchell \& Hall, 2001b), interest in wine (Hall, 1996), wine knowledge (Charters \& Ali-Knight, 2002; Mitchell \& Hall, 2001a, 2001b; J. J. Yuan et al., 2005a), generations (Dodd, Yuan, Adams, \& Kolyesnikova, 2006), country of origin (Alonso, Fraser, \& Cohen, 2007), repeat visitors versus first timers (Bruwer \& Lesschaeve, 2012), and festival information sources (Shanka \& Taylor, 2004), rather than motivations. Because this study does not contextualize the Dalian festival directly within tourism studies and the notion of a discrete Chinese wine festival tourist seeking a total tourism experience, we hope to create new knowledge gap about festival motivations. The study seeks to understand what might be a new basis for a sound, long-term understanding of wine festival attendees in China by considering the internal psychographic dimensions of motivation. Motives are the "starting point that launches the decision process" (Crompton \& McKay, 1997, p. 425), with Iso-Ahola (1980) describing a motive as "an internal factor that arouses, directs, and integrates a person's behaviour” (p. 230). An understanding of event motives can be useful when designing offerings for event attendees, monitoring satisfaction, and trying to understand attendees' decision-making processes (Crompton \& McKay, 1997).

Although the decision to visit a festival is a directed action, which is triggered by a desire to meet a need (Crompton \& McKay, 1997), there is a wide range of motives that bring people to festivals. A corpus of literature has seen motivational measurement scales developed, tested, and validated with push factors emerging related to escape, dream fulfillment, identity fulfillment, personal growth, family togetherness, and pull factors might include a natural and historic environment, cost, facilities, and safety (Crompton \& McKay, 1997; Iso-Ahola, 1989; Mohr, Backman, Gahan, \& Backman, 1993; Scott, 1996; Uysal, Gahan, \& Martin, 1993). As few studies have focused on wine festivals (see Table 1) and none in China, wine festival attendees can be motivated to attend a wine festival for a number of reasons. In addition, the extents to which different wine festivals attract those with different motivations or whether there are underlying common motivations remains contentious. Although the empirical studies shown in Table 1 indicate that delineated motivation factors found in various wine festival studies have some similar components (Uysal \& Li, 
Table 1

Previous Wine Festival Motivational Research

\begin{tabular}{|c|c|c|c|}
\hline Researchers (Year) & Selected Event & Delineated Motivation Factors & Methodology \\
\hline Isaykina (2001) & Wine festival, Texas, USA & $\begin{array}{l}\text { Relaxation, socialization, entertainment, and } \\
\text { family togetherness }\end{array}$ & $\begin{array}{l}\text { 7-point Likert } \\
\text { scale }\end{array}$ \\
\hline $\begin{array}{l}\text { Nicholson and } \\
\text { Pearce (2001) }\end{array}$ & $\begin{array}{l}\text { Marlborough Wine, Food and } \\
\text { Music Festival, New Zealand, } \\
\text { and } 3 \text { other festivals }\end{array}$ & $\begin{array}{l}\text { Socialization, event novelty/uniqueness, escape, } \\
\text { and family }\end{array}$ & $\begin{array}{l}\text { 5-point Likert } \\
\text { scale }\end{array}$ \\
\hline $\begin{array}{l}\text { Weiler et al. } \\
\text { (2004) }\end{array}$ & Winter Wine Festival, Australia & $\begin{array}{l}\text { Cultural exploration, known-group socialization, } \\
\text { event novelty, external socialization, family } \\
\text { togetherness, and recovering equilibrium }\end{array}$ & $\begin{array}{l}\text { 5-point Likert } \\
\text { scale }\end{array}$ \\
\hline Dodd et al. (2006) & $\begin{array}{l}\text { GrapeFest, Texas and the Vintage } \\
\text { Indiana, USA Wine and Food } \\
\text { Festival }\end{array}$ & $\begin{array}{l}\text { Enjoying entertainment, finding thrills and } \\
\text { excitement, and being with friends }\end{array}$ & $\begin{array}{l}\text { 7-point Likert } \\
\text { scale }\end{array}$ \\
\hline $\begin{array}{l}\text { J. J. Yuan et al. } \\
\text { (2006) }\end{array}$ & $\begin{array}{l}\text { Vintage Indiana Wine and Food } \\
\text { Festival }\end{array}$ & $\begin{array}{l}\text { Festival and escape, wine, socialization, and } \\
\text { family togetherness }\end{array}$ & $\begin{array}{l}\text { 7-point Likert } \\
\text { scale }\end{array}$ \\
\hline Park et al. (2008) & $\begin{array}{l}\text { South Beach Wine and Food } \\
\text { festival, Miami Beach, Florida }\end{array}$ & $\begin{array}{l}\text { Taste new wine and food, enjoy the event, } \\
\text { enhance social status, escape from routine life, } \\
\text { meet new people, spend time with family, and } \\
\text { meeting the celebrity and wine experts }\end{array}$ & $\begin{array}{l}\text { 7-point Likert } \\
\text { scale }\end{array}$ \\
\hline
\end{tabular}

2008), the same underlying factors may not been seen in China.

Wine festival motivational research has not delved into whether significant differences in motivation occur between different visitor groups. Although Saaymanm, Marais, and Krugell (2010) used oneway ANOVA to evaluate perceptions regarding the managerial aspects of a wine festival, and Fountain and Ryan (2016) used it to explore the role of involvement in motivations; ANOVA testing hasn't been used extensively in wine festival motivational research.

\section{Method}

\section{Measures and Sampling}

The main objective of this study is the exploration of motivating factors at the 2012 Dalian International Wine and Dine Festival, and whether motivating factors are influenced by particular social, demographic, and cultural factors. The second objective is to profile wine festival attendees, while the final study objective is to identify the push and pull motives essential for a marketing strategy for wine festivals in China. The questionnaire design utilized motivations scales from Crompton (1979) and Iso-Ahola (1982), and is conceptually grounded in their work. A conceptual framework that utilized sociopsychological motivational domains (pull and push factors) was found to be an appropriate framework to develop the criterion to explore motivation. Validated motivational scale items were taken from studies by Isaykina (2001), Nicholson and Pearce (2001), Park, Reisinger, and Kang (2008), Weiler, Truong, and Griffiths (2004), and J. J. Yuan, Jang, Cai, Morrison, and Linton, (2006). The seven domains used in this study were cultural exploration (3 items), festival novelty/regression (4 items), recover equilibrium (4 items), known-group socialization (3 items), external interaction/socialization (3 items), family togetherness (3 items), and wine festival (3 items). The motivational items were measured on a 5-point Likert-type scale (1=extremely important, 5=not at all important) to indicate the extent to which respondents agreed or disagreed on the importance of each item in regard to why they attended the event. Additional demographic questions (gender, age, marital status, level of education, employment status, and income) were added, along with wine-related questions (wine knowledge, previous visits to wineries, and source of wine knowledge).

The wine festival motivation questionnaires were administered at the Dalian International Wine Festival. There are multiple plans for new wineries surrounded by high-end French styled chateaux resort properties that offer resort-style activities with scenic views and lush wines in the province. Jin Shi 
Tan Resort, for example, an hour drive away from Dalian, is the home of the Chateau de Bordeaux-a huge real estate project with villas, semidetached homes, town houses, and apartments all built in the style of French chateau. Owned by the Chinese Haichang Group and France's Lamont Winery Group, they also intend to build Asia's largest wine museum and theme park that will include 333.3 ha of grapes, a French wine school, and a China-French Wine Cultural Exchange Center (Dong \& Yang, 2011). Ten student volunteers were trained to help distribute and collect the self-administered questionnaire to festival attendees over 2 days of the International Wine Festival in Dalian, China in July 2012. The questionnaire was developed in English by the authors, and then translated into simplified Chinese by a Chinese bilingual academic translator who was independent of the study. Before being distributed, the questionnaire was then translated back to ensure accuracy (Brislin, 1970). To reduce the risk of measurement inaccuracy, two bilingual tourism and events tourism professors were asked to check if the questionnaire was contextually accurate rather than merely a literal translation. Although not representing the general population, the sample represents a specific portion of the festival population. The student volunteers were located at multiple distribution points in the festival grounds and collected 499 questionnaires (21 times as many observations as there are variables to be analyzed). A nonprobability, purposive sample was used. Anonymity was ensured and consent was obtained from all participants.

Statistical analyses were computed using the Windows versions of Statistical Package for Social Sciences (SPSS) version 22.0. Factor analysis, independent samples $t$ test, and one-way ANOVA were used to achieve the study purposes. Factor analysis was conducted to reduce the number of variables and to detect structure in the relationships between variables. Then, with the classified variables, an independent samples $t$ test was conducted to investigate gender differences among attendees and their motivations of visiting the wine festival. In order to determine if differences existed, one-way ANOVA procedures were conducted with a chosen level of significance at 0.05 to evaluate differences between age, education, and income, and visitors' scores on the identified factor domains. A post hoc analysis was utilized to clarify the nature of any significant differences. As a means to indicate scale reliability (internal consistency), Cronbach’s alpha (Cronbach, 1951) was used to determine the internal consistency. As Likert-type rating scales are susceptible to response styles, point 1 (extremely important) and point 5 (not at all important) were removed, with 366 remaining questionnaires. This is because extreme responding such as choosing an endpoint of a rating scale is often high in countries that have a low tolerance for uncertainty and ambiguity (van Dijk, Datema, Piggen, Welten, \& van de Vijver, 2009).

Results and Analysis

\section{Participants Profile}

As sociodemographic characteristics of wine festival attendees are not well developed (Getz, Carlsen, Brown, \& Havitz, 2008), descriptive analysis (Table 2) were used to gain a picture of the sample. There were as many males (50\%) as females (50\%) surveyed, with the majority of respondents aged between 18 and 44 years (88.8\%). The majority of respondents were single (58.5\%) with a bachelor's degree or above (90.7\%), and a majority were currently working (56.8\%).

From the wine experience involvement questions, the study found that the majority of respondents (56.3\%) had not previously been to any wine festivals, and only $7.7 \%$ had visited a winery. Whereas $57.4 \%$ had limited to no knowledge of wine, $45.4 \%$ were knowledgeable or highly knowledgeable. Wine drinkers comprised $85.6 \%$ of respondents. Only $11.5 \%$ of respondents attended the festival alone, with $40.2 \%$ attending with family.

\section{Exploratory Factor Analysis}

Exploratory factor analysis was used to examine interrelationships among dependent variables and explain the variables' common underlying components, to find the most important. Although the study utilized a wide range of predetermined scale items contextualized for a wine festival, we sought to utilize exploratory factor analysis to uncover the underlying structure of the 23 variables, so as not to limit an understanding of motivators. This is because 
Table 2

Sociodemographic Profile of Respondents

\begin{tabular}{lc}
\hline Characteristics & Number (Percentage \%) \\
\hline Gender & \\
Female & $183(50.0)$ \\
Male & $183(50.0)$ \\
Age & \\
18-24 & $152(41.5)$ \\
25-44 & $173(47.3)$ \\
45-64 & $37(10.1)$ \\
65 and over & $4(1.1)$ \\
Marital status & \\
Single & $214(58.5)$ \\
Married & $147(40.2)$ \\
Other & $5(1.4)$ \\
What is the highest level of education you have obtained? & \\
High school graduate or lower & $58(15.8)$ \\
Bachelor's degree or equivalent & $274(74.9)$ \\
Graduate degree & $34(9.3)$ \\
What is your current employment Status? & $208(56.8)$ \\
Working & $22(6.0)$ \\
Currently not employed & $12(3.3)$ \\
Retired/on a pension & $119(32.0)$ \\
Studying & $5(1.4)$ \\
Other (e.g., self-employed) & \\
What is your monthly individual income (RMB)? & $165(45.2)$ \\
Under 3000 (\$483) & $109(29.9)$ \\
3,001-5,000 (\$483-\$805) & $53(14.5)$ \\
5,001-8,000 (\$805-\$1,290) & $22(6.0)$ \\
8,001-15,000 (\$1,290-\$2,400) & $16(4.4)$ \\
More than 15,000 (\$2,400) & \\
\hline
\end{tabular}

event goers can exhibit different motivations at different events (Crompton \& McKay, 1997; X. Li \& Petrick, 2006; Nicholson \& Pearce, 2000, 2001). To determine the factorability of the data, the KaiserMeyer-Olkin (KMO) measure of sampling adequacy and Bartelett's test of sphericity were checked. According to Kaiser (1974), an acceptable minimum $\mathrm{KMO}$ value is 0.50 . The researchers conducted an exploratory factor analysis using principal component analysis with Varimax rotation and a factor extraction according to the MINEIGEN criterion (i.e., all factors with eigenvalues greater than 1). Table 3 illustrates the results of the PCA (rotation method: Varimax with Kaiser normalization), which converged after 6 iterations, retaining 22 of the variables, each of which loaded onto one of four factors with eigenvalues $>1$ and high $(>0.538)$ factor loadings relative to the sample size (Stevens, 1992). The KMO measure of sampling adequacy was 0.904 (meritorious; Kaiser, 1974) and along with the Bartlett's test of sphericity (3546.01, $p=0.0001$ ) confirms the validity of the PCA (cf. Norusis, 2005). The reliability of the four-factor solution was high, with reliability coefficients for the four factors well above the accepted level of 0.70 (Nunnally, 1978). Thus, those factors were utilized for further analysis, one-way ANOVA, and independent samples $t$ test.

The exploratory factor analysis identified four established coherent subsets that are relatively independent of one another based on the 22 scale variables ("I like to go to festival with a group"-KGS was deleted). The themes were relabeled as wine festival (WF), recover equilibrium at a novel event (REN), family and known group togetherness (FKG), and cultural exploration through interaction/socialization (CEI). The original components were cultural exploration (CE), festival novelty/regression (FN), recover equilibrium (RE), known-group socialization (KGS), interaction/socialization (IS), family togetherness (TG), and wine festival (WF). The elimination and amalgamation of components are not overly surprising given 
Table 3

Factor Analysis of Wine Festival Visitors' Motivations

\begin{tabular}{|c|c|c|c|c|}
\hline Impact Items & Factor Loading & Eigenvalue & $\begin{array}{l}\text { Variance } \\
\text { Explained }\end{array}$ & $\begin{array}{l}\text { Reliability } \\
\text { Coefficient }\end{array}$ \\
\hline Wine festival (WF) & & 9.270 & 38.624 & 0.890 \\
\hline While at the festival, I want to engage in wine tasting & 0.679 & & & \\
\hline While at the festival, I want to buy wines & 0.682 & & & \\
\hline $\begin{array}{l}\text { While at the festival, I want to increase y knowledge and appre- } \\
\text { ciation of food, wine, and music }\end{array}$ & 0.756 & & & \\
\hline I came to festival to enjoy a unique festive atmosphere & 0.633 & & & \\
\hline While at the festival, I want to increase my wine knowledge & 0.724 & & & \\
\hline $\begin{array}{l}\text { I go to festivals like this to relieve boredom and escape from } \\
\text { routine life }\end{array}$ & 0.576 & & & \\
\hline $\begin{array}{l}\text { I like to go to the festival to be with an observe the other people } \\
\text { who are attending }\end{array}$ & 0.778 & & & \\
\hline Recover equilibrium at a novel event (REN) & & 2.296 & 9.568 & 0.874 \\
\hline $\begin{array}{l}\text { I am attending the festival to recover from my usually hectic } \\
\text { pace of life }\end{array}$ & 0.683 & & & \\
\hline $\begin{array}{l}\text { I came to festival because it sounded like fun, entertaining, and } \\
\text { exciting }\end{array}$ & 0.685 & & & \\
\hline $\begin{array}{l}\text { I came to the festival because I enjoy special types of events } \\
\text { I don't have usually the chance to attend }\end{array}$ & 0.595 & & & \\
\hline $\begin{array}{l}\text { I like to attend festivals like this to reduce built-up tension, } \\
\text { anxieties, and frustrations }\end{array}$ & 0.547 & & & \\
\hline $\begin{array}{l}\text { I came to the festival because I was curious and wanted to try } \\
\text { something new }\end{array}$ & 0.582 & & & \\
\hline $\begin{array}{l}\text { I go to festival because it is a chance to be with people who are } \\
\text { enjoying themselves }\end{array}$ & 0.601 & & & \\
\hline Family and known group togetherness (FKG) & & 1.319 & 5.494 & 0.865 \\
\hline I came to festival to do something the family could do together & 0.848 & & & \\
\hline I go to festival so I can be with my friends/companion(s) & 0.668 & & & \\
\hline I like visiting this festival to spend time with family & 0.845 & & & \\
\hline I came to the festival to bring my family closer together & 0.821 & & & \\
\hline Cultural exploration through interaction (CEI) & & 1.190 & 4.957 & 0.784 \\
\hline $\begin{array}{l}\text { When attending the festival, I like to meet new people with } \\
\text { similar interests }\end{array}$ & 0.657 & & & \\
\hline $\begin{array}{l}\text { I came to festival to enjoy one of the few unique cultural things } \\
\text { to do in Dalian }\end{array}$ & 0.569 & & & \\
\hline $\begin{array}{l}\text { I like to go to the festival to be with and observe the people } \\
\text { who are attending }\end{array}$ & 0.646 & & & \\
\hline I go to festival to be with others who enjoy the same things I do & 0.682 & & & \\
\hline $\begin{array}{l}\text { I want to experience customs and cultures at the festival that is } \\
\text { different from those in my own environment }\end{array}$ & 0.509 & & & \\
\hline
\end{tabular}

discrepancies are an inherent problem with the composition of scales, with novel contexts often generating unique domain components.

The "wine festival" (WF) component indicates that the respondents sought, with others, to engage in wine tasting, wines purchases, knowledge and appreciation of food, wine, and music, enjoy the atmosphere, relieve boredom, and observe others. Like other festivals (C. K. Lee, Lee, \& Wicks, 2004; Park et al., 2008; van Zyl \& Botha, 2004; Yoon \& Uysal, 2005; J. J. Yuan et al., 2006), the event speaks for itself, with those attending seeking to experience the festival by way of wine tasting sessions, wine appreciation classes, and opportunities to both bid for and buy wine. The "recover equilibrium at a novel event" (REN) component follows on from Nicholson and Pearce (2001) and Weiler et al. (2004), who also found that consuming wines at a unique event was novel. The findings also indicate a link to recovery as it generates a sort of status-related pride. The study found that respondents were motivated to attend because they were curious and wanted to try something new, because it sounded like fun, entertaining and exciting, and 
because they enjoyed special types of events they don't usually have the chance to attend. They also linked attendance at this unique event to recovery from a hectic pace of life, and as a means to reduce built-up tension, anxieties, and frustrations at an event where people were enjoying themselves. Therefore, we can see that novelty and recovery are important "pull" and "intrinsic" motives. This interrelation between novelty and recovery was also identified by T. Lee and Crompton (1992). They found that the novelty "pull" construct was related to respondents seeking out new and different experiences based on their needs to experience thrill, adventure, and surprise. The "family and known group togetherness" (FKG) component has been found repeatedly across various studies dealing with festival visitors motivations (Mohr et al., 1993), including wine festivals (Isaykina, 2001; Nicholson \& Pearce, 2001; Park et al., 2008, Weiler et al., 2004; Yuan et al., 2006). The "cultural exploration through interaction/socialization” (CEI) component is an important factor that motivates people to attend a festival, with other motivational factors often based on the type of the event.

\section{Independent Samples t Test and one-way ANOVA}

An independent sample $t$ test was conducted to evaluate whether there were differences between gender and the festival attendees' scores on the four components. Only the "family and known group togetherness" (FKG) component showed significant results, $t(363)=30.7, p=0.002$, with female respondents $(M=14.51, S D=4.68)$ on average having a higher score on the component than males $(M=$ $12.99, S D=4.81$ ). In order to determine if differences existed, one-way ANOVA procedures were conducted to evaluate differences between age, education, employment status, and income and visitors' scores on the identified factor domains. A one-way ANOVA was conducted to evaluate whether a relationship existed between attendees' age and festival motivations. The "cultural exploration through interaction/socialization” (CEI) component showed significant results, $F(3,359)=15.594, p=0.006$. The dependent variable, age groups, included four levels: 18-24, 25-44, 45-64, and 65 and above. The independent variable was the CEI component of the motivations. Because there were four levels of age groups, a post hoc analysis was conducted in order to determine the nature of the significance. In the post hoc analysis using the Tukey test, those aged between 18 and $24(M=18.17, S D=4.107)$ showed higher scores than other groups. The FKG component also showed significant results $F(3,361)=$ 85.689, $p=0.010$. In the post hoc analysis using the Tukey test, those aged between 45 and $64(M=$ 15.5946, $S D=3.989$ ) showed higher scores than other groups.

A one-way ANOVA was conducted to evaluate whether a relationship existed between attendees' educational level and their scores on the wine festival visit motivations. The FKG component showed significant results $F(2,362)=143.231, p=0.002$. Because there were three levels of education, a post hoc analysis was conducted in order to determine the nature of the significance. In the post hoc analysis using the Tukey test, those with a high school diploma or lower $(M=15.66, S D=4.093)$ showed higher scores on valuing family and known group togetherness than other groups.

A one-way ANOVA was conducted to evaluate whether a relationship existed between attendees' employment level and their scores on the wine festival visit motivations. The "wine festival” (WF) component showed significant results, $F(4,360)=$ $170.615, p=0.01$. Because there were five levels of employment status, a post hoc analysis was conducted in order to determine the nature of the significance. In the post hoc analysis, those "employed" ( $M=28.26, S D=5.916)$ showed higher scores than other groups. This suggests that respondents who were employed were significantly more motivated by the wine festival itself compared to other employment groups. The CEI component also showed significant results, $F(4,358)=116.838, p=0.00$. In the post hoc analysis, students $(M=18.53, S D=3.712)$ showed higher scores than others. The "recover equilibrium at a novel event" (REN) component also showed significant results, $F(4,360)=$ $116.838, p=0.01$. In the post hoc analysis, students $(M=23.98, S D=4.295)$ showed higher stores than other groups.

A one-way ANOVA was conducted to evaluate whether a relationship existed between attendees' marital status and their scores on the wine festival visit motivations. The FKG component showed significant results, $F(2,362)=8.022, p=0.00$. Because 
there were three levels of marital status, a post hoc analysis was conducted in order to determine the nature of the significance. In the post hoc analysis, those who are married $(M=14.90, S D=4.567)$ showed higher scores on valuing family and known group togetherness than other groups. It was found that wine knowledge and previous visits to wineries have no significant influence on motivations.

\section{Discussion}

This study was carried out to understand underlying motivational components for attending a cultural wine festival at an up and coming city in China, and whether motivation varied with respect to the sociodemographic composition of attendees. Within the context-specific area of a festival, different motivating factors can emerge because of the festival location (rural, urban), size, the focus (wine, dine, imported wines), the target audience, and whether the event is free and open to the public or ticketed. In general, the study found that the four components that make up the motivation factor structure do not neatly follow the findings from Western festival motivational studies given the strong pull of the event in general, the importance of family togetherness, and the cultural exploration through interaction/socialization. Although the study did not seek to assess prevailing cultural values, the participating sample supported aspirational and collectivist values, though some of these values are changing in the younger generations (e.g., Wang \& Gagné, 2013). The study results point to the strength of family, and indicate female attendees place a greater significance on the family and known group togetherness component than other attendees. It is possible to assume that more Chinese female attendees than male attendees visited the festival so that the family could do something together and bring family closer together. It also extended to spending time with friends, partners, and companion(s).

The finding that respondent's gender is strongly related to the motive is not unusual, with many festival motivational studies finding that female visitors are more likely to attend festival events with a high motivation of family and known group togetherness (Duran \& Hamarat, 2014; Yolal, Cetinel, \& Uysal, 2009). This motive may be more pronounced in China where event and travel participation is influenced by family togetherness and kinship enhancement motives (Huang \& Hsu, 2005). The study revealed a pattern regarding the FKG component with older married attendees with less education placing more importance on family togetherness. Van Zyl and Botha (2004) also found that the oldest group of festival visitors placed more importance on family togetherness than younger groups. Park et al. (2008) found that Chinese attendees also valued family togetherness in comparison to North American festival attendees. The relationship between marital status and the FKG has been studied and has found contradictory results. Uysal et al. (1993) and J. J. Yuan et al. (2005a) found married visitors assigned greater priority in spending time with family than single visitors. Although Formica and Uysal (1998) reached the opposite conclusion, our findings confirm the former. The finding is important as it confirms that the festival is used as a venue for family activities and vacations. However, family togetherness only explains $5.49 \%$ of the variance with a reliability of 0.86 . This may reflect the fact that only $40 \%$ of attendees visited the festival as part of a family group.

The younger age group of attendees (18-24 years old) showed that they were motivated to attend the wine festival because of cultural exploration through interaction/socialization (CEI). The finding that there was significant variation related to age is not surprising considering the significance and nature of the festival. The component is both people and place oriented with attendees motivated to visit the festival to be with others who enjoy the same things as they did, meet new people with similar interests, to be with and observe the other people who are attending, and enjoy unique cultural things, customs, and cultures. Therefore, we can see that the unique cultural things, customs, and cultures available at the festival were the means to interact with others with similar cultural and consumption interests. The nature of the wine festival provided the means for a large number of people with common interests and goals to gather together.

Attendees who were students were found to be motivated by "recover equilibrium at a novel event" (REN) and "cultural exploration through interaction/socialization” (CEI). It suggests students were significantly more motivated by new and different experiences compared to other employment groups. 
Contradictory findings have been found in previous festival studies, with no clear link between recover equilibrium, event novelty components, and sociodemographic variables (Abreu-Novais \& Arcodia, 2013). However, the findings indicate that younger attendees and students were motivated to learn wine culture and develop a sense of self through social interaction. We conclude that cultural characteristics may be a key issue here, as cultural exploration and knowledge transfer is linked to interaction in informal settings like events and festivals. Interpersonal relationships (Chinese "guanxi”) rely heavily on communication, cultural knowledge, with liquor playing a unique role in the interactions between people in China (W. Yuan, Zhang, \& Goodfellow, 1998).

The finding that specific wine festival dimensions and specific characteristics are significant has been routinely found in wine festival motivation studies (Nicholson \& Pearce, 2001; Park et al., 2008; J. J. Yuan et al. 2005a). However, the wine festival component explains $38.62 \%$ of the variance with a reliability of 0.89 . This exceeds other motivational finding linked to specific characteristics of wine festivals found in the previous studies such as $7.63 \%$ in Isaykina (2001) and $15.10 \%$ in Park et al. (2008). The relative importance of this component was higher in the attendees who were employed. The findings suggest that attendees visited the wine festival for wine. However, in many festival studies, the specific festival theme were not eventspecific motives (Chang \& Yuan, 2011). Although finding that the specifics matter (WF), wine festivals must also offer recover equilibrium at a novel event (REN), family and known group togetherness (FKG), and cultural exploration through interaction/socialization (CEI). There is no doubt that the emergence of a middle class, the pluralization of lifestyles, and the rise in experiential interests in China are reconstituting event spaces. They provide a tangible place where class-specific subjects and their cultural milieu are created, staged, and contested. The researchers found the festival was a space by which members of families would gather, a space where strangers socialize and network, and a space to increase knowledge of wine. Although some attendees are motivated to attend the festival because of what it specifically offers, other features are also strong motivations for attendance (Backman, Backman, Uysal, \& Sunshine, 1995; van Zyil \& Botha, 2004; Yolal et al., 2009). These findings allow the organizers to form an integrated festival that serves all these motives. Although accentuating wine at its core, the organizers should incorporate family-friendly spaces and activities, as well as create more private spaces to socialize and interact. In the longer term, such interventions may enlarge attendance, increase attendee satisfaction, and promote repeat visitation.

The researchers found that the findings conform to motivation studies conceptually grounded in the push and pull model (Crompton, 1979; Dann, 1981) and the escape-seek dichotomy (Iso-Ahola, 1982), which remain a useful conceptual basis for understanding festival motivation in diverse cultural contexts (Alebaki \& Iakovidou, 2010; van Zyl \& Botha, 2004; Yolal et al., 2009). However, we also confirm the findings by Nicholson and Pearce (2001), who noted that "different events appear to attract different audiences” (p. 458) with eventspecific factors important. Although the study found that "push and pull" and "escape-seek" factors were interrelated (Snepenger, King, Marshall, \& Uysal, 2006; Uysal \& Jurowski, 1994), they also suggest a unique motivational structure. This framework contains mixed push-pull/escapes-seek factors, with attendee behavior driven by interrelated internal and external factors that suggest the influence of cultural context.

\section{Conclusion}

With a growing number of festivals emerging in China, this motivational study explored a locally based culturally emergent event. As wine producers, cooperatives, wine festivals, retail outlets, and destination manager's event seek to better understand Chinese consumers, this study reveals that there are four main motivational components explaining why people attended the 2012 Dalian wine festival. The findings show both cross-cultural similarities and differences in festival motivations, and point to the lack of generalizability of festival motivations to a Chinese context. The study also found evidence that motivations vary depending on sociodemographic 
variables, and point to China as a geographic context where empirical studies that focus on specific motivations to attend festivals need to be carried out. As more wine festivals emerge in Wuwei city (Gansu province), Yantai (Shandong province), Jinh'an (Shanghai), Ningxia, and other locations, it is important to incorporate motivational research findings to allow organizers, wine producers, and other stakeholders to effectively target and develop markets, and compete on a national level.

\section{References}

Abreu-Novais, M., \& Arcodia, C. (2013). Music festival motivators for attendance: Developing an agenda for research. International Journal of Event Management Research, 8(1), 34-48.

Alebaki, M., \& Iakovidou, O. (2010). Segmenting the Greek wine tourism market using a motivational approach. New Medit, 9(4), 31-40.

Alonso, A., Fraser, R. A., \& Cohen, D. A. (2007). Investigating differences between domestic and international winery visitors in New Zealand. International Journal of Wine Business Research, 19, 114-126.

Arnold, N. (1999). Marketing and development models for regional communities: A Queensland experience. In Proceedings of the 9th Australian Tourism and Research Hospitality Conference, CAUTHE 1999, Adelaide, South Australia, Bureau of Tourism Research, Canberra, Australia.

Backman, K. F., Backman, S. J., Uysal, M., \& Sunshine, K. M. (1995). Event tourism: An examination of motivations and activities. Festival Management \& Event Tourism, 3(1), 15-24.

Brislin, R. W. (1970). Back-translation for cross-cultural research. Journal of Cross-Cultural Psychology, 1(3), 185-216. doi: 10.1177/135910457000100301

Brown, G., \& Getz, D. (2006). Critical success factors for wine tourism regions: A demand analysis. Tourism Management, 27(1), 146-158. doi: 10.1016/j.tourman.2004. 08.002

Bruwer, J., \& Lesschaeve, I. (2012). Wine tourists' destination region brand image perception and antecedents: Conceptualization of a winescape framework. Journal of Travel \& Tourism Marketing, 29(7), 611-628. doi: 10.1080/10548408.2012.719819

Carlsen, J. (2004). Review of global wine tourism research. Journal of Wine Research, 15(1), 5-13. doi: 10.1080/09 57126042000300281

Carlsen, J., \& Charters, S. (Eds.). (2004). Global wine tourism: Research, management and marketing. Wallingford, UK: CABI.

Chang, W., \& Yuan, J. (2011). A taste of tourism: Visitors' motivations to attend a food festival. Event Management, 15(1), 13-23. doi: 10.3727/152599511X12990855575024
Charters, S., \& Ali-Knight, J. (2002). Who is the wine tourist? Tourism Management, 23(3), 311-319. doi: 10.1016/ S0261-5177(01)00079-6

Crompton, J. L. (1979). Motivations for pleasure vacation. Annals of Tourism Research, 6(4), 408-424. doi: 10.1016/ 0160-7383(79)90004-5

Crompton, J. L., \& McKay. S. L. (1997). Motives of visitors attending festival events. Annals of Tourism Research, 24(2), 425-439. doi: 10.1016/S0160-7383(97)80010-2

Cronbach, L. J. (1951). Coefficient alpha and the internal structure of tests. Psychometrika, 16(3), 297-334. doi: 10.1007/BF02310555

Dann, G. (1981). Tourist motivation: An appraisal. Annals of Tourism Research, 8(2), 187-219. doi: 10.1016/01607383(81)90082-7

Dewar, K., Meyer, D., \& Li, W. M. (2001). Harbin, lanterns of ice, sculptures of snow. Tourism Management, 22(5), 523-532. doi: 10.1016/S0261-5177(01)00007-3

Dodd, T., Yuan, J., Adams, C., \& Kolyesnikova, N. (2006). Motivation of young people for visiting wine festivals. Event Management, 10(1), 23-33. doi: 10.3727/152599 506779364660

Dong, J., \& Yang, J. (2011). Dalian invests 3 billion yuan to brew the world's top-grade wine. Retrieved from http://dalian.chinadaily.com.cn/2011-12/14/content_ 14262372.htm

Duran, E., \& Hamarat, B. (2014). Festival attendees’ motivations: The case of International Troia Festival. International Journal of Event and Festival Management, 5(2), 146-163.

Formica, S., \& Uysal, M. (1998). Market segmentation of an international cultural-historical event in Italy. Journal of Travel Research, 36(4), 16-24.

Fountain, J., \& Ryan, G. (2016). Motivations to attend a New Zealand wine and food festival: The role of involvement. In 9th International Conference of the Academy of Wine Business Research (AWBR), February 17-18, University of South Australia, Adelaide, Australia. Retrieved from http://academyofwinebusiness.com/wp-content/uploads/ 2016/03/Conference-Proceedings-Final_TOC_Final.pdf

Getz, D. (2000). Explore wine tourism: Management, development and destinations. Elmsford, NY: Cognizant Communication Corporation.

Getz, D., Carlsen, J., Brown, G., \& Havitz, M. (2008). Wine tourism and consumers. In A. G. Woodside \& D. Martin (Eds.), Tourism management: Analysis, behaviour and strategy (pp. 245-268). Wallingford, UK: CABI.

Hall, C. M. (1996). Wine tourism in New Zealand. In J. Higham (Ed.), Proceedings of tourism down under II: A tourism research conference (pp. 109-119). Dunedin, New Zealand: University of Otago.

Huang, S., \& Hsu, C. H. C. (2005). Mainland Chinese residents' perceptions and motivations of visiting Hong Kong: Evidence from focus group interviews. Asia Pacific Journal of Tourism Research, 10(2), 191-205.

Isaykina, E. (2001). Defining the target market and motivations for visiting the GrapeFest Wine Festival in 
Grapevine, Texas. Master thesis, Texas Tech University, Lubbock, TX.

Iso-Ahola, S. E. (1980). The social psychology of leisure and recreation. Dubuque, IA: Wm. C. Brown.

Iso-Ahola, S. E. (1982). Toward a social psychological theory of tourism motivation: A rejoinder. Annals of Tourism Research, 9, 256-262. doi: 10.1016/0160-7383 (82)90049-4

Iso-Ahola, S. E. (1989). Motivation for leisure. In E. L. Jackson \& T. L. Burton (Eds.), Understanding leisure and recreation: Mapping the past, charting the future (pp. 247-279). State College, PA: Venture Publishing.

Jago, L., Chalip, L., Brown, G., Mules, T., \& Ali, S. (2003). Building events into destination branding: Insights from experts. Event Management, 8(1), 3-4. doi: 10.3727/15 2599503108751658

Kaiser, H. F. (1974). An index of factorial simplicity. Psychometrika, 39(1), 31-36. doi: 10.1007/BF02291575

Lee, C. K., Lee, Y. K., \& Wicks, B. E. (2004). Segmentation of festival motivation by nationality and satisfaction. Tourism Management, 25(1), 61-70. doi: 10.1016/ S0261-5177(03)00060-8

Lee, T., \& Crompton, J. (1992). Measuring novelty seeking in tourism. Annals of Tourism Research. 19(4), 732-751. doi: 10.1016/0160-7383(92)90064-V

Li, Y-N., \& Wood, E. H. (2016). Music festival motivation in China: Free the mind. Leisure Studies, 35(3), 332-351. doi: 10.1080/02614367.2014.962588

Li, X., \& Petrick, J. F. (2006). Research note: A review of festival and event motivations studies. Event Management, 9(4), 239-245. doi: 10.3727/152599506776771526

Ma, L. J. C. (2002). Urban transformation in China, 19492000: A review and research agenda. Environment and Planning A, 34(9), 1545-69. doi: 10.1068/a34192

Mitchell, R., \& Hall, C. M. (2001a). The influence of gender and region on the New Zealand winery visit. Tourism Recreation Research, 26(2), 63-75. doi: 10.1080/02508 281.2001.11081344

Mitchell, R., \& Hall, C. M. (2001b). Lifestyle behaviours of New Zealand winery visitors: Wine club activities, wine cellars and place of purchase. International Journal of Wine Marketing, 13(3), 82-93. doi: 10.1108/eb00 8729

Mitchell, R., \& Hall, C. M. (2006). Wine tourism research: The state of play. Tourism Review International, 9(4), 307-332. doi: 10.3727/154427206776330535

Mohr, K., Backman, K. F., Gahan, L. W., \& Backman, S. J. (1993). An investigation of festival motivations and event satisfaction by visitor type. Festival Management \& Event Tourism, 1(3), 89-97. doi: 10.3727/10652709 3792337619

Nicholson, R., \& Pearce, D. G. (2000). Who goes to events: A comparative analysis of the profile characteristics of visitors to four South Island events. Journal of Vacation Marketing, 6(3), 236-253. doi: 10.1177/135676670000 600304

Nicholson, R., \& Pearce, D. G. (2001). Why do people attend events: A comparative analysis of visitor motivations at four south island events. Journal of Travel Research, 39(4), 449-460. doi: 10.1177/004728750103900412

Norusis, M. (2005). Advanced statistical procedures companion. Upper Saddle River, NJ: Prentice Hall.

Nunnally, J. C. (1978). Psychometric theory. New York, NY: McGraw-Hill Publishing Company.

Organization of Vine and Wine. (2015). OIV report on the world vitivinicultural situation. Retrieved from http:// www.oiv.int/public/medias/2246/press-release-2015bilan-vin-en-oiv.pdf

Park, K. S., Reisinger, Y., \& Kang, H. J. (2008). Visitors' motivation for attending the South Beach Wine and Food Festival, Miami Beach, Florida. Journal of Travel \& Tourism Marketing, 25(2), 161-181. doi: 10.1080/10 548400802402883

Saayman, M., Marais, M., \& Krugell, W. (2010). Measuring success of a wine festival: Is it really that simple? South African Journal for Research in Sport, Physical Education and Recreation, 32(2), 95-107. doi: 10.4314/sajrs. v32i2.59299

Scott, D. (1996). A comparison of visitors' motivations to attend three urban festivals. Festival Management and Event Tourism, 3(3), 121-128.

Shanka, T., \& Taylor, R. (2004). A correspondence analysis of sources of information used by festival visitors. Tourism Analysis, 9(1-2), 55-62. doi: 10.3727/108354 2041437602

Snepenger, D., King, J., Marshall, E., \& Uysal, M. (2006). Modeling Iso-Ahola's motivation theory in the tourism context. Journal of Travel Research, 45(2), 140-149. doi: 10.1177/0047287506291592

Steers, R. M., Mowday, R. T., \& Shapiro, D. L. (2004). The future of work motivation theory. Academy of Management Review, 29(3), 379-387. doi: 10.5465/AMR.2004. 13670978

Stevens, J. P. (1992). Applied multivariate statistics for the social sciences (2nd ed.). Hillsdale, NJ: Erlbaum.

Taylor, R., \& Shanka, T. (2002). Attributes for staging successful wine festivals. Event Management, 7(3), 165175. doi: 10.3727/152599502108751569

Uysal, M., Gahan, L., \& Martin, B. (1993). An examination of event motivations: A case study. Festival Management \& Event Tourism, 1(1), 5-10.

Uysal, M., \& Jurowski, C. (1994). Testing the push and pull factors. Annals of Tourism Research, 21(4), 844-846. doi: 10.1016/0160-7383(94)90091-4

Uysal, M., \& Li, X. (2008). Trends and critical issues in festival \& event motivation. In A. Aktas, M. Kesgin, E. Cengiz, \& E. Yenidip (Eds.), International cultural \& event tourism: Issues and debates (pp. 10-20). Ankara, Turkey: Detay Yayincilik.

van Dijk, T. K., Datema, F., Piggen, A.-L. J. H. F., Welten, S. C. M., \& van de Vijver, F. J. R. (2009). Acquiescence and extremity in cross-national surveys: Domain dependence and country-level correlates. In A. Gari \& K. Mylonas (Eds.), Quod erat demonstrandum: From Herodotus' ethnographic journeys to cross-cultural research (pp. 149158). Athens, Greece: Pedio Books Publishing. 
van Zyl, C. V., \& Botha, C. (2004). Motivational factors of local residence to attend the Aardklop National Arts Festival. Event Management, 8(4), 213-222. doi: $10.3727 / 1525995031436818$

Wang, Z., \& Gagné, M. (2013). A Chinese-Canadian crosscultural investigation of transformational leadership, autonomous motivation and collectivistic value. Journal of Leadership and Organizational Studies, 20(1), 134-142. doi: 10.1177/1548051812465895

Weiler, B., Truong, M., \& Griffiths, M. (2004, May). Visitor profiles and motivations for visiting an Australian Wine Festival. In J. Carlsen \& S. Charters (Eds.), International wine tourism research. Proceedings of the International Wine Tourism Conference, Margaret River, Western Australia, Perth: Vineyard Publications.

Yoon, Y., \& Uysal, M. (2005). An examination of the effects of motivation and satisfaction on destination loyalty: A structural model. Tourism Management, 26(1), 45-56. doi: 10.1016/j.tourman.2003.08.016

Yolal, M., Çetinel, F., \& Uysal, M. (2009). An examination of festival motivation and perceived benefits relationship: Eskişehir International Festival. Journal of
Convention \& Event Tourism, 10(4), 276-291. doi: 10.1080/15470140903372020

Yuan, J. J., Cai, L. A., Morrison, A. M., \& Linton, S. (2005a). An analysis of wine festival attendees' motivations: A synergy of wine, travel and special events? Journal of Vacation Marketing, 11(1), 41-58. doi: 10.1177/1356766705050842

Yuan, J. J., Cai, L. A., Morrison, A. M., \& Linton, S. (2005b). Segmenting wine festival attendees: A factor-cluster approach. Tourism Review International, 8(4), 297-309. doi: 10.3727/154427205774791500

Yuan, J. J., Jang, S. S., Cai, L. A., Morrison, A. M., \& Linton, S. J. (2006). Analysis of motivational and promotional effects of a wine festival. In J. Carlsen \& S. Charters (Eds.), Global wine tourism: Research, management and marketing (pp. 196-208). Wallingford, UK: CABI.

Yuan, J. J., Morrison, A. M., Cai, L. A., \& Linton, S. J. (2008). A model of wine tourist behaviour: A festival approach. International Journal of Tourism Research, 10(3), 207-219. doi: 10.1002/jtr.651

Yuan, W., Zhang, X. S., \& Goodfellow, R. (1998). Business culture in China. Singapore: Academic Publishing Asia. 